\title{
Secondary tumours of the ampulla of Vater: Case report and review of the literature
}

\author{
FRANCESCA SAROCCHI ${ }^{1}$, MAGDALENA M. GILG ${ }^{1,2}$, FLORIAN SCHREIBER $^{3}$ and CORD LANGNER $^{1}$ \\ ${ }^{1}$ Institute of Pathology, and ${ }^{2}$ Department of Orthopedics and Trauma Surgery, Medical University \\ of Graz, A-8036 Graz; ${ }^{3}$ Department of Internal Medicine, Division of Gastroenterology \\ and Hepatology, Medical University of Graz, A-8036 Graz, Austria
}

Received July 6, 2017; Accepted November 23, 2017

DOI: $10.3892 / \mathrm{mco} .2017 .1535$

\begin{abstract}
Secondary tumours of the ampulla of Vater are rare. Underlying primary tumours, clinical presentation, macroscopic appearance, treatment strategies and outcome of secondary ampullary lesions have not been systematically analysed. The present case study reported a 57-year old patient with an ampullary metastasis from renal cancer and a literature review was performed in which a further 32 patients were included. The most common responsible primary tumours were malignant melanoma and renal clear cell carcinoma, followed by breast cancer. The time interval between the diagnosis of the primary tumour and the ampullary metastasis was highly variable, and may be as long as 10 years, particularly for renal cancer. Patients may present with unspecific abdominal discomfort, jaundice or upper gastrointestinal bleeding. The gross appearance was largely indistinguishable from that of a primary tumour. Lesions may present as polypoid or irregular, soft and friable tumour mass, in certain cases with superficial ulceration. In $\sim 50 \%$ of cases, the ampullary metastasis was the only metastatic lesion, while in the remaining cases, the cancer had spread to one or more organs. The prognosis was generally poor. The management requires a multi-modal approach, including endoscopic, surgical and oncological procedure.
\end{abstract}

\section{Introduction}

The ampulla of Vater was first described in a detailed manner by Abraham Vater in 1720 and it consists of three different anatomical structures: the duodenum, the terminal tract of the pancreatic duct and the final portion of the common bile duct (1). These elements have distinct functions and histological features, comprising intestinal, pancreatobiliary and gastric mucosal types (2).

Correspondence to: Dr Cord Langner, Institute of Pathology, Medical University of Graz, Auenbruggerplatz 25, A-8036 Graz, Austria

E-mail: cord.langner@medunigraz.at

Key words: ampulla of Vater, ampullary tumour, metastasis, secondary tumour, histology, differential diagnosis
Primary ampullary cancer comprises two main histological subtypes, the pancreatobiliary type and the intestinal type, but also rarer variants such as signet ring cell, adenosquamous, mucinous, clear cell, papillary, and neuroendocrine carcinoma $(3,4)$. Adsay et al (2) classified ampullary cancers into four subtypes based upon their location which reflects different prognosis: intra-ampullary, peri-ampullary/duodenal, ampullary-ductal and ampullary lesions not otherwise specified. Occasionally, tumours of the pancreatic head or distal bile duct may extend into the ampullary region, thereby mimicking a primary ampullary neoplasm.

Several malignancies have been reported to involve the upper gastrointestinal tract in a secondary manner and among these lung cancer, breast cancer and malignant melanoma seem to be the most common primary sites (5). Within the upper gastrointestinal tract, the stomach is more often affected by secondary tumours than the duodenum. However, metastasis to the ampulla of Vater is exceedingly rare, with only 31 cases reported so far (6-33).

Herein we report the case of a 57-year-old patient who developed ampullary metastasis from renal cell carcinoma 3.5 years following initial diagnosis. Additionally, we conducted a systematic and comprehensive literature review summarizing all cases of secondary ampullary tumours documented in MEDLINE/PubMed until December 2016.

\section{Case report}

A 57-year-old male patient presented with subacute upper gastrointestinal bleeding 3.5 years at the Department of Gastroenterology, Medical University of Graz (Graz, Austria) following nephrectomy for renal clear cell carcinoma (pT3b, G2, N0, M0, R0). The requirement for written informed consent was waived for the present case report. The patient did not undergo any further adjuvant treatment but had regular follow-up until the occurrence of upper gastrointestinal bleeding. Upon gastroscopy, the ampulla of Vater was irregularly enlarged, vulnerable (Fig. 1A), and multiple biopsies were taken. All other parts of the upper gastrointestinal tract were entirely normal.

Histology showed well differentiated cancer cells with clear cytoplasm and small to moderately enlarged, hyperchromatic nuclei. The tumour cells were arranged in alveolar pattern (Fig. 1B-C) and were detected mainly in the submucosa 

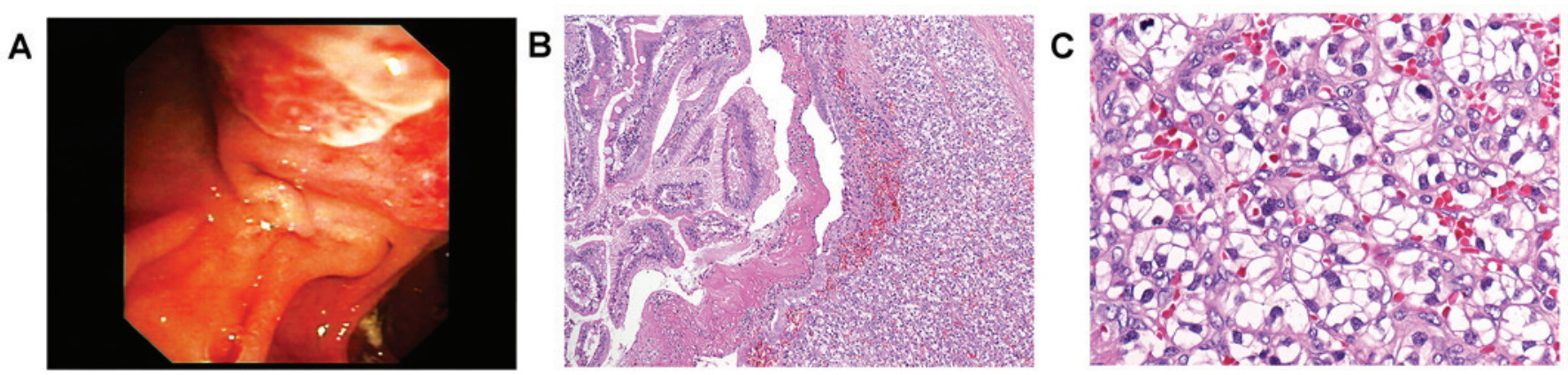

Figure 1. A, irregular enlargement of the ampulla. B, renal clear cell carcinoma which is developed mainly in the submucosa with secondary ulceration of the mucosal surface (original magnification, x100) C, well differentiated cancer cells arranged in typical alveolar pattern (original magnification, x250).

with secondary ulceration of the mucosal surface. Findings ultimately prompted diagnosis of secondary ampullary carcinoma, that is, metastatic disease from renal cell cancer.

Staging including CT of chest, abdomen and pelvis as well as whole body bone scan did not reveal further metastatic lesions. The patient underwent pylorus-preserving pancreaticoduodenectomy (Whipple procedure). Macroscopic workup of the surgical specimen showed a yellowish tumour mass within the ampulla, measuring $3 \mathrm{~cm}$ in largest diameter. All surgical resection margins and all dissected lymph nodes were free of cancer. The postoperative course was uneventful, and the patient discharged on postoperative day 15 . Since then, the patient undergoes regular controls, including CT scans of the abdomen in regular intervals and there is now, four years after resection, no evidence of local recurrence or distant metastasis.

\section{Discussion}

We presented a rare case of secondary tumour of the ampulla of Vater. The corresponding primary tumour was renal clear cell carcinoma that had been operated 3.5 years earlier. Following pancreaticoduodenectomy, the patient is free of cancer for four years now.

A total of 32 secondary tumours, including our own case, have been reported to occur within the ampulla so far (Table I). Mean age at diagnosis of the secondary tumour is 56 years (median 55; range 27-81) (6-33). Renal carcinoma $(\mathrm{n}=11 ; 34 \%)$, malignant melanoma $(n=10 ; 31 \%)$ and breast cancer $(n=4,13 \%)$ are the most common corresponding primary tumours. These three entities account for approximately three fourths of cases.

The mean time interval (known for 29 patients) between the diagnosis of the primary tumour and the ampullary metastasis is 4.8 years (median 3.5; range 0-17.5). However, lesions may also be detected synchronously with the primary tumour $(n=5)$. Of note, time intervals for metastatic renal cancer lesions are particularly long (mean 8.8 years, median 10 years; range $0-17.5)$. In only one third of patients $(n=12,38 \%)$, as in the presented case, the ampullary metastasis was the only metastatic lesion, while in the remaining patients cancer spread to one or more organs was observed, most commonly to brain, liver, lungs, and bone. Notably, the majority of malignant melanomas showed involvement of several distant organs (Table I).

Clinical symptoms of secondary ampullary tumours are unspecific and similar to the presentation of primary tumours.
Affected individuals may present with abdominal discomfort $(n=13,41 \%)$, jaundice and related symptoms $(n=18,56 \%)$, such as pruritus or alterations in stool and urine or with upper gastrointestinal bleeding $(\mathrm{n}=11,34 \%)$.

Likewise, endoscopic presentation is indistinguishable from that of primary tumours apart from metastatic melanomas which occasionally appear as pigmented lesions $(34,35)$. According to the data retrieved from literature, the majority $(n=24 / 26,92 \%)$ of lesions are polypoid and irregular, soft and friable masses which can also be ulcerated. In addition to endoscopy, several imaging methods, such as transpapillary intraductal ultrasonography and computed tomography, may be applied to detect small lesions of the papilla and to provide a proper staging (36). However, criteria to differentiate primary from secondary ampullary tumours have not been developed for these techniques. Definitive diagnosis requires clinical data and standard biopsies: cyto-architectural appearance and immunohistochemical profile are analysed to exclude primary neoplasms or less common lesions, e.g., sarcomas, GISTs and malignant lymphomas (37). In the evaluation of primary ampullary tumours, the diagnostic accuracy of forceps biopsies is known to range from 47 to $95 \%$ (37). False negative results may result from submucosal localisation of the tumour, and it is expected that the diagnostic accuracy for secondary tumours is lower, as these usually do not originate for the mucosa, but affect the luminal surface in a secondary manner (37).

As the prognosis of patients with secondary ampullary tumours is poor and a surgical approach bears a considerable risk of postoperative morbidity and mortality surgical intervention should be planned carefully (38). Outcome data was available for 19 patients. Three patients (16\%), including our own patient, remained free of cancer after surgery for more than 2.5 years $(2.5,4,5$ years, respectively) and one patient is alive with residual disease 6.5 years following resection (Table I). Notably, all four of them were patients with metastatic renal cell carcinoma.

Data regarding therapeutic strategies were available in $31(97 \%)$ patients and one half of patients underwent a surgical procedure $(n=16)$, including Whipple resection $(n=10)$. A total of 15 (48\%) patients received chemotherapy, either in addition to surgery or alone. Drainage and/or stenting were applied in $10(31 \%)$ patients, in five patients combined with chemotherapy. For small lesions, endoscopic (or surgical) ampullectomy appears to be an alternative with reduced length of inpatient stay, lower morbidity and mortality (38). However, endoscopic 


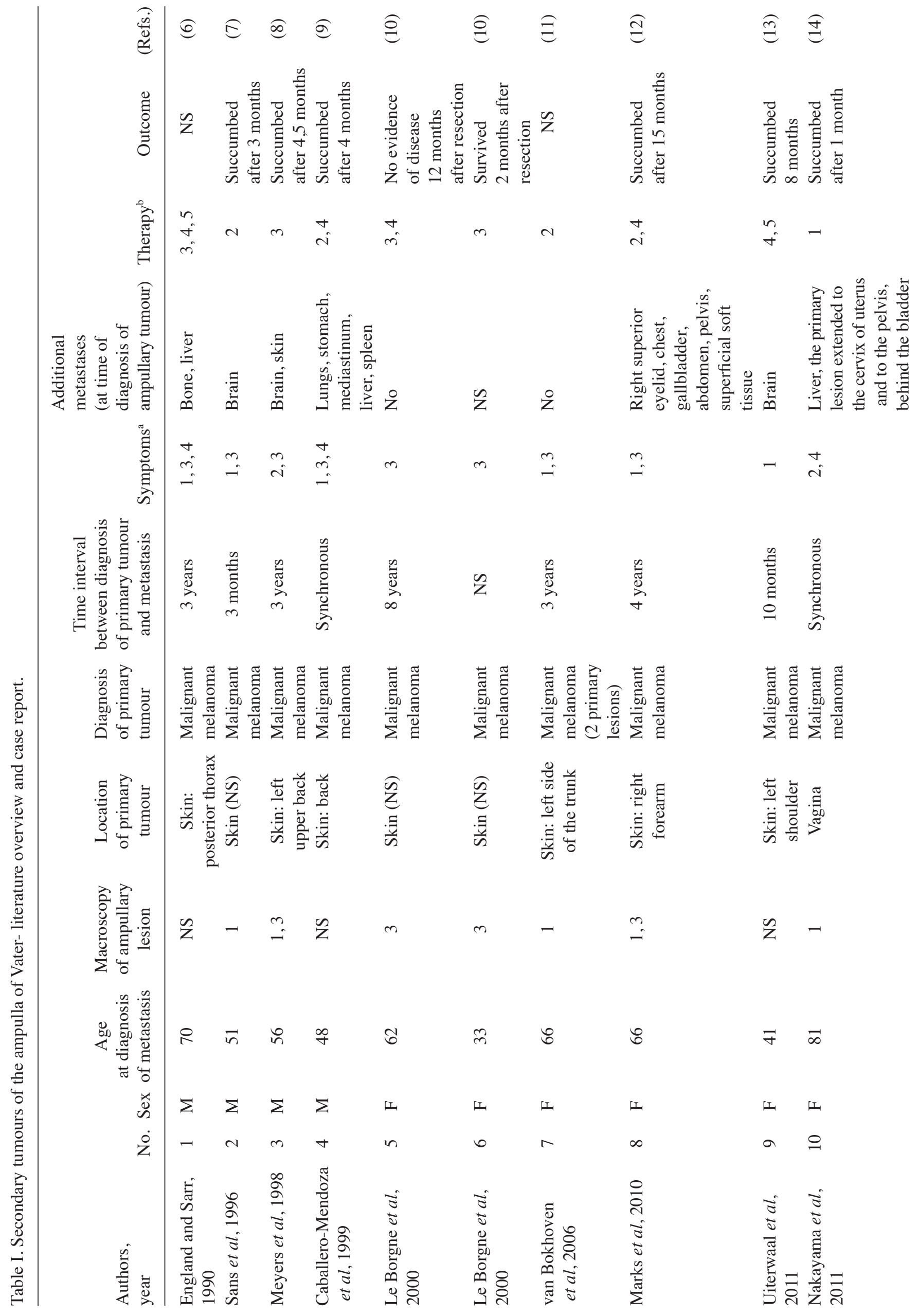




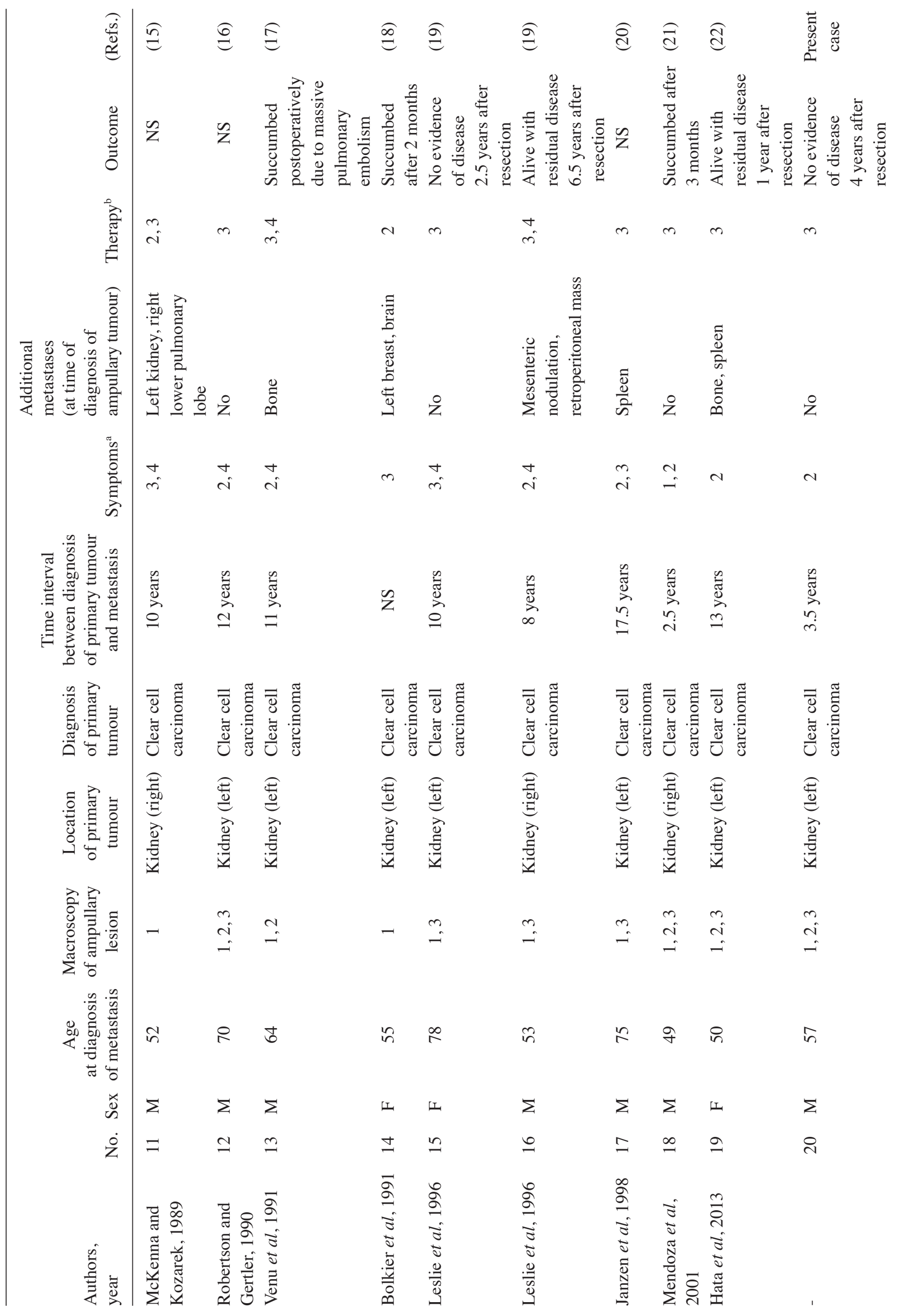




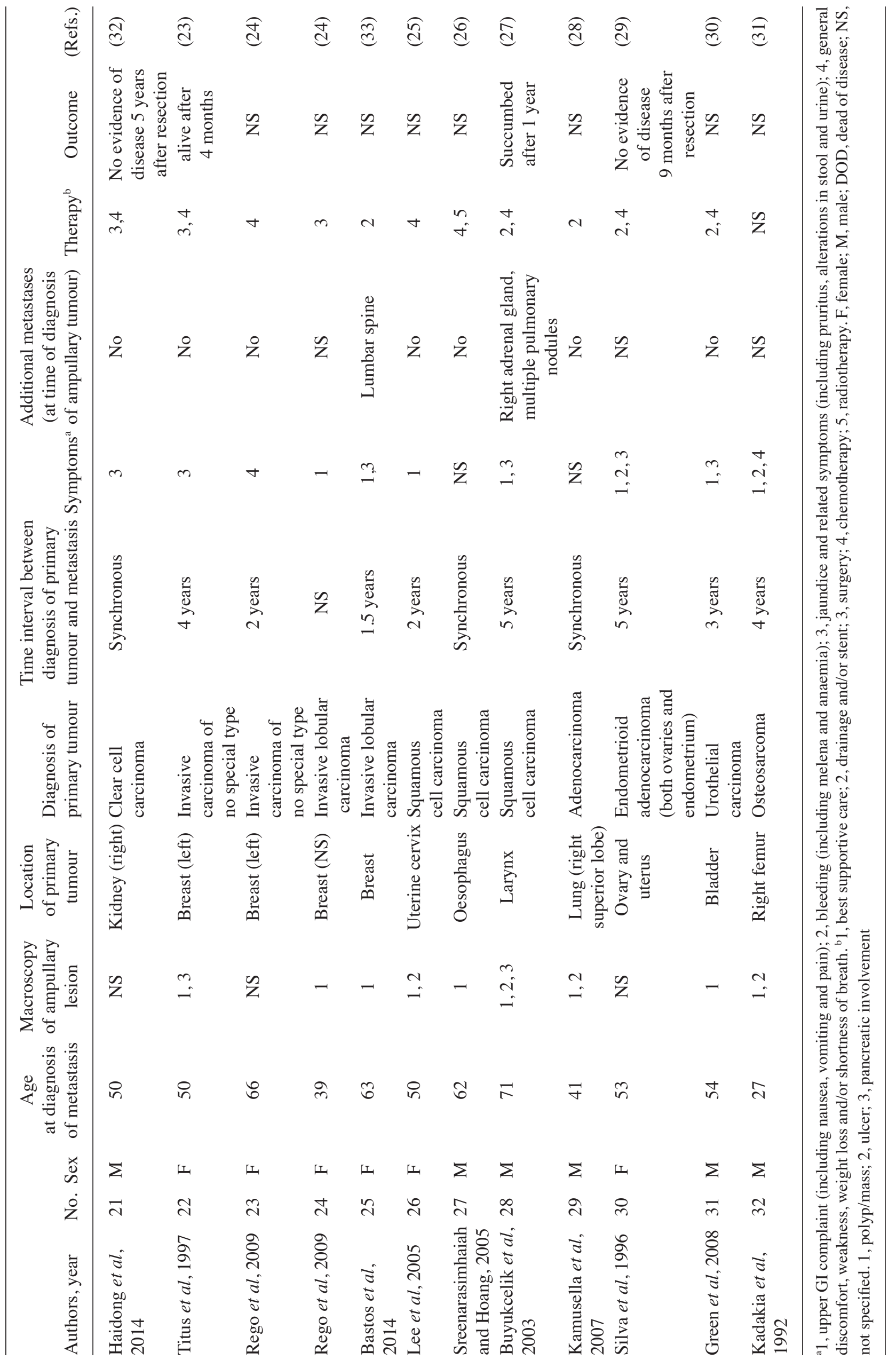


ampullectomy is considered a 'high-risk' procedure due to potential complications (39). These can be classified as early (pancreatitis, bleeding, perforation, and ampullectomy reported from large, tertiary care referral centres varies between 8 and $35 \%$ (39). So far, this technique has not been applied for secondary ampullary lesions, but it could be the best approach in cases presenting with mechanical cholestasis or even cholangitis and poor prognosis due to progress of the systemic malignant disease.

As seen in our case, ampullary metastases from renal cell cancer seem to behave differently both in terms of time intervals until the development of secondary tumours and overall prognosis. Similarly, in renal cell carcinoma metastatic to the stomach the mean time interval until the detection of a secondary tumour to the ampulla was around ten years (40). When complete resection of all metastatic lesions can be achieved patient show improved survival (41). Thus, Whipple resection with or without pylorus preservation which is the standard treatment for primary ampullary cancer may be also performed in these cases when all metastatic sites are amenable to wide resection $(42,43)$.

In conclusion, secondary tumours of the ampulla of Vater are uncommon and malignant melanoma, renal and breast cancer are the most frequent primaries. Patients may present with jaundice or upper gastrointestinal bleeding. The time interval between the diagnosis of the primary tumour and the ampullary metastasis is highly variable and may be $>10$ years, particularly in patients with renal cancer. The management of metastatic ampullary lesions requires a multi-modal approach, including endoscopic, surgical, and oncological procedures.

\section{References}

1. Horiguchi S and Kamisawa T: Major duodenal papilla and its normal anatomy. Dig Surg 27: 90-93, 2010.

2. Adsay V, Ohike N, Tajiri T, Kim GE, Krasinskas A, Balci S, Bagci P, Basturk O, Bandyopadhyay S, Jang KT, et al: Ampullary region carcinomas: Definition and site specific classification with delineation of four clinicopathologically and prognostically distinct subsets in an analysis of 249 cases. Am J Surg Pathol 36: 1592-1608, 2012.

3. Perysinakis I, Margaris I and Kouraklis G: Ampullary cancer--a separate clinical entity? Histopathology 64: 759-768, 2014.

4. Albores-Saavedra JHR, Klimstra DS and Zamboni G: Invasive adenocarcinoma of the ampullary region 2. In: WHO Classification of Tumours of the Digestive System. Bosman FTCF, Hruban RH and Theise ND (eds). IARC Press, Lyon, pp87-91, 2010.

5. Wei SC, Su WC, Chang MC, Chang YT, Wang CY and Wong JM: Incidence, endoscopic morphology and distribution of metastatic lesions in the gastrointestinal tract. J Gastroenterol Hepatol 22 827-831, 2007.

6. England MD and Sarr MG: Metastatic melanoma: An unusual cause of obstructive jaundice. Surgery 107: 595-596, 1990.

7. Sans M, Llach J, Bordas JM, Andreu V, Campo A, Castells A, Mondelo E, Terés J and Rodés J: Metastatic malignant melanoma of the papilla of Vater: An unusual case of obstructive cholestasis treated with biliary prostheses. Endoscopy 28: 791-792, 1996.

8. Meyers MO, Frey DJ and Levine EA: Pancreaticoduodenectomy for melanoma metastatic to the duodenum: A case report and review of the literature. Am Surg 64: 1174-1176, 1998.

9. Caballero-Mendoza E, Gallo-Reynoso S, Arista-Nasr J and Angeles-Angeles A: Obstructive jaundice as the first clinical manifestation of a metastatic malignant melanoma in the ampulla of vater. J Clin Gastroenterol 29: 188-189, 1999.

10. Le Borgne J, Partensky C, Glemain P, Dupas B and de Kerviller B: Pancreaticoduodenectomy for metastatic ampullary and pancreatic tumors. Hepatogastroenterology 47: 540-544, 2000.
11. van Bokhoven MM, Aarntzen EH and Tan AC: Metastatic melanoma of the common bile duct and ampulla of Vater. Gastrointest Endosc 63: 873-874, 2006.

12. Marks JA, Rao AS, Loren D, Witkiewicz A, Mastrangelo MJ and Berger AC: Malignant melanoma presenting as obstructive jaundice secondary to metastasis to the Ampulla of Vater. JOP 11: 173-175, 2010.

13. Uiterwaal MT, Mooi WJ and Van Weyenberg SJ: Metastatic melanoma of the ampulla of Vater. Dig Liver Dis 43: e8, 2011.

14. Nakayama H, Miyazaki S, Kikuchi H, Saito N, Shimada H, Sakai S, Suzuki M and Kimura K: Malignant vaginal melanoma with metastases to the papilla of Vater in a dialysis patient: A case report. Intern Med 50: 345-349, 2011.

15. McKenna JI and Kozarek RA: Metastatic hypernephroma to the ampulla of Vater: An unusual cause of malabsorption diagnosed at endoscopic sphincterotomy. Am J Gastroenterol 84: 81-83, 1989.

16. Robertson GS and Gertler SL: Late presentation of metastatic renal cell carcinoma as a bleeding ampullary mass. Gastrointest Endosc 36: 304-306, 1990.

17. Venu RP, Rolny P, Geenen JE, Hogan WJ, Komorowski RA and Ferstenberg R: Ampullary tumor caused by metastatic renal cell carcinoma. Dig Dis Sci 36: 376-378, 1991.

18. Bolkier M, Ginesin Y, Moskovitz B, Munichor M and Levin DR: Obstructive jaundice caused by metastatic renal cell carcinoma. Eur Urol 19: 87-88, 1991

19. Leslie KA, Tsao JI, Rossi RL and Braasch JW: Metastatic renal cell carcinoma to ampulla of Vater: An unusual lesion amenable to surgical resection. Surgery 119: 349-351, 1996.

20. Janzen RM, Ramj AS, Flint JD, Scudamore CH and Yoshida EM: Obscure gastrointestinal bleeding from an ampullary tumour in a patient with a remote history of renal cell carcinoma: A diagnostic conundrum. Can J Gastroenterol 12: 75-78, 1998

21. Mendoza JL, Lana R, Defarges V, Meroño E, Candía A and Loscos JM: Late metastasis of hypernephroma of the Vater's ampulla. Rev Esp Enferm Dig 93: 606-608, 2001.

22. Hata T, Sakata N, Aoki T, Yoshida H, Kanno A, Fujishima F, Motoi F, Masamune A, Shimosegawa T and Unno M: Repeated pancreatectomy for metachronous duodenal and pancreatic metastases of renal cell carcinoma. Case Rep Gastroenterol 7: 442-448, 2013

23. Titus AS, Baron TH, Listinsky CM and Vickers SM: Solitary breast metastasis to the ampulla and distal common bile duct. Am Surg 63: 512-515, 1997.

24. Rego RF, Atiq M, Velchala N, Nevin D, McElreath DP, McKnight WD and Aduli F: Ampullary metastasis from breast cancer: An unusual finding. Endoscopy 41 (Suppl 2): E278-E279, 2009.

25. Lee TH, Park SH, Lee CK, Lee SH, Chung IK, Kim SJ and Kim SW: Ampulla of Vater metastasis from recurrent uterine cervix carcinoma presenting as groove pancreatitis. Gastrointest Endosc 73: 362-363, 2011.

26. Sreenarasimhaiah J and Hoang MP: Esophageal squamous cell carcinoma with metastasis to the ampulla. Gastrointest Endosc 62: 310-311, discussion 311, 2005.

27. Büyükçelik A, Ensari A, Sarioğlu M, Işikdogan A and Içli F: Squamous cell carcinoma of the larynx metastasized to the ampulla of Vater. Report of a case. Tumori 89: 199-201, 2003.

28. Kamusella P, Wissgott C and Steinkamp HJ: [Extrahepatic biliary obstruction caused by papillary metastasis of pulmonary adenocarcinoma]. RoFo Fortschr Geb Rontgenstr Nuklearmed 179: 1272-1273, 2007

29. Silva R, Paiva ME and Santos CC: Obstructive jaundice caused by ampullary metastases of an endometrioid adenocarcinoma. Gastrointest Endosc 44: 195-197, 1996.

30. Green D, Rowsell C and Cohen L: Metastatic bladder carcinoma to ampulla of Vater. Gastrointest Endosc 68: 199-200, 2008.

31. Kadakia SCPA, Parker A and Canales L: Metastatic tumors to the upper gastrointestinal tract: Endoscopic experience. Am J Gastroenterol 87: 1418-1423, 1992.

32. Haidong W, Jianwei W, Guizhong L, Ning L, Feng H and Libo M: Ampullary tumor caused by metastatic renal cell carcinoma and literature review. Urol J 11: 1504-1507, 2014.

33. Bastos T, Souza TF, Otoch JP, Grecco E, Àvila F and Artifon EL: Metastasis of breast cancer to major duodenal papilla. Rev Gastroenterol Peru 34: 149-150, 2014.

34. Buissin D, Sterle A, Schmiegelow P, Wassenberg D and Ambe PC: Primary anorectal malignant melanoma: a rare but aggressive tumor: report of a case. World J Surg Oncol 13: 12, 2015.

35. Weigt J and Malfertheiner P: Metastatic Disease in the Stomach. Gastrointest Tumors 2: 61-64, 2015. 
36. Ito K, Fujita N, Noda Y, Kobayashi G and Horaguchi J: Diagnosis of ampullary cancer. Dig Surg 27: 115-118, 2010.

37. Wiech T, Walch A and Werner M: Histopathological classification of nonneoplastic and neoplastic gastrointestinal submucosal lesions. Endoscopy 37: 630-634, 2005.

38. Ceppa EP, Burbridge RA, Rialon KL, Omotosho PA, Emick D, Jowell PS, Branch MS and Pappas TN: Endoscopic versus surgical ampullectomy: An algorithm to treat disease of the ampulla of Vater. Ann Surg 257: 315-322, 2013.

39. De Palma GD, Masone S, Rega M, Simeoli I, Donisi M, Addeo P, Iannone L, Pilone V and Persico G: Metastatic tumors to the stomach: Clinical and endoscopic features. World J Gastroenterol 12: 7326-7328, 2006

40. Pollheimer MJ, Hinterleitner TA, Pollheimer VS, Schlemmer A and Langner C: Renal cell carcinoma metastatic to the stomach: Single-centre experience and literature review. BJU Int 102: 315-319, 2008.

41. Leibovich BCCJ, Cheville JC, Lohse CM, Zincke H, Frank I, Kwon ED, Merchan JR and Blute ML: A scoring algorithm to predict survival for patients with metastatic clear cell renal cell carcinoma: A stratification tool for prospective clinical trials. J Urol 174: 1759-1763, discussion 1763, 2005.
42. Hornick JR, Johnston FM, Simon PO, Younkin M, Chamberlin M, Mitchem JB, Azar RR, Linehan DC, Strasberg SM, Edmundowicz SA, et al: A single-institution review of 157 patients presenting with benign and malignant tumors of the ampulla of Vater: Management and outcomes. Surgery 150: 169-176, 2011.

43. Klein F, Jacob D, Bahra M, Pelzer U, Puhl G, Krannich A, Andreou A, Gül S and Guckelberger O: Prognostic factors for long-term survival in patients with ampullary carcinoma: The results of a 15-year observation period after pancreaticoduodenectomy. HPB Surg 2014: 970234, 2014.

(2) This work is licensed under a Creative Common Attribution-NonCommercial-NoDerivatives 4.0 International (CC BY-NC-ND 4.0) License. 